\title{
Implementation of the Flood Risk Management Directive in Selected European Countries
}

\author{
Uwe Müller* \\ Saxon State Agency for Environment, Agriculture and Geology, Dresden, Saxony 01109, Germany
}

\begin{abstract}
Flood events are a recurrent threat to economic developments and can jeopardize human existence. In order to reduce the flood risks in Europe on a sustainable basis, the European Union adopted the Flood Risk Management Directive in 2007. The implementation of the directive in the national laws of all member states has laid the foundation for intergovernmental integrated flood risk management on an European scale. The following article is intended to compare and briefly assess the implementation process on inland waters at the technical level in selected European countries in the middle of the process. It covers the different basic structural, methodological, and data conditions for preparing the preliminary flood risk assessment, the flood hazard maps, the flood risk maps, and the flood risk management plans as a result of two EU projects. The technical differences in the various European countries need to be reduced in the next cycles of implementation of the Flood Risk Management Directive.
\end{abstract}

Keywords European Union, flood hazard maps, flood risk awareness, flood risk management plans, flood risk maps, integrated flood risk management, preliminary flood risk assessment

\section{Introduction}

The European Flood Risk Management Directive (European Union 2007), which was adopted in 2007, strives for a coordinated uniform European approach to handle the negative impacts of flood events. European Union (EU) member states have created the legal basis by translating the directive into national law. The process of implementation of the Flood Risk Management Directive (FRMD) during the next few years will include flood risk assessments, flood hazard maps, and flood risk maps, as well as flood risk management plans to be implemented for the reduction of the flood risk. The actual work on these issues at the technical level shows areaspecific or methodology-related differences, which requires coordination between the states.

The current technical discussions on the implementation of the Flood Risk Management Directive should be used to

\footnotetext{
* E-mail: Uwe.Mueller@smul.sachsen.de
}

make a gradual change from a safety culture to a risk culture in Europe. Internationally, the existing security approach is increasingly being replaced by a risk culture. The first step considers holistically, what could happen (risk analysis). Then the risk is assessed. This takes into account what should not happen and at what price security can be realized (risk assessment). As a result of the risk assessment, the best risk control measures are derived (risk management). Table 1 shows the difference between safety and risk approaches.

A part of the technical implementation of the FRMD has been tested in several EU projects, for example, project LABEL (LABEL: Labe and Elbe-combination of the river name in Czech and German) (LABEL Website 2011) and the FloodWise project (FloodWise 2011). One of the main aims of project LABEL was the preparation of an agreement on joint applications to flood risk management and the implementation of the EU flood risk management guidelines in the Elbe River basin. The main objective of FloodWise was to improve cross-border flood risk management in European river basins that cross national borders.

\section{The European Flood Risk Management Directive}

In the wake of the large floods during the 1990s and the extreme flood event in Middle Europe in 2002, the EU became aware of floods as a serious threat to the economic development and general existence in European communities. The major technical issues in the implementation to the Flood Risk Management Directive were: floods have the potential to cause fatalities, displacement of people, damage to the environment, and severely compromise economic development and undermine economic activities; floods are natural phenomena which cannot be prevented; some human activities (such as settlements) and the climate change contribute to an increase in the likelihood and adverse impacts of flood events; measures to reduce the flood risks within a river basin should be coordinated on a transnational basis; and measures related to water or land use should be verified for their impacts on the flood risk. Flood risk management objectives must take into account local and regional conditions and 
Table 1. Difference between safety and risk approaches

\begin{tabular}{lll}
\hline & Safety Approach & Risk Approach \\
\hline Central question & How can we protect ourselves & What safety at what cost \\
Collected events & Frequent & Frequent and infrequent \\
Significance of the hazards & Not known & Known, evaluation included \\
Action planning & Technically & Interdisciplinary \\
Comparison of measures & Hardly possible & $\begin{array}{l}\text { Efficacy can be compared, acceptance based on } \\
\text { efficacy }\end{array}$ \\
Control of the use of resources & Sectoral & Active, prioritization of overall view \\
Safety & For the present generation, high in individual sectors & $\begin{array}{l}\text { Solidarity with future generations, balanced for the } \\
\text { overall system }\end{array}$ \\
\hline
\end{tabular}

Source: Grünewald (2003).

emphasize the great importance of the solidarity (upstream/ downstream) principle in flood risk management. The principle of solidarity means that the upstream riparian may not take any flood protection measures that increase the risk of flooding for downstream residents. It is even better if the upstream riparian implements its measures in a way that results in an improvement to the downstream population.

The Flood Risk Management Directive, whose main objective is to reduce flood risk, is a logical addition to the environmental objectives laid down in the EU Water Framework Directive (European Union 2000). Both directives cannot be implemented without integrated management of the river basins. Three basic steps are required to ensure the implementation of the Flood Risk Management Directive.

\subsection{Preliminary Flood Risk Assessment}

By 22 December 2011, all member states had to complete a preliminary flood risk assessment based on information already available or easily obtainable: records and studies on long-term trends (for example, demography); information on the impact of climate changes on flood events; maps of the river basin districts showing river basins, topography, and land use; description of the floods that have occurred in the past and had significant adverse impacts on the protected assets taking into account the topography; hydrological and other technical data dealing with floodplains; existing flood control infrastructures; and vulnerability of the assets to be protected. This preliminary assessment will be reviewed and updated in 2018 and the process will be repeated every 6 years.

\subsection{Flood Hazard and Flood Risk Maps}

In a second phase ending 22 December 2013, flood hazard maps and flood risk maps must be drawn up for the areas and zones exposed to significant flood risk as identified according to the given criteria. The maps must be prepared for low-probability floods (extreme events), medium-probability floods ( $\geq 100$ years) and, where appropriate, for highprobability floods. The flood hazard maps should show the flood extent, water depth or water level as appropriate, and, where appropriate, the flow velocity or relevant water flows. The flood risk maps should contain information on the number of inhabitants potentially affected, the type of economic activity of the area potentially affected, the integrated pollution and prevention control (IPPC) installations as referred to in Directive 96/61/EC (European Union 1996), the potentially affected protected areas identified according to the EU Water Framework Directive (WFD), and other information such as sediments and contaminants. The maps will be updated in 2019 and then every 6 years.

\subsection{Flood Risk Management Plans}

The third and final step to be completed by 22 December 2015 requires the development of flood risk management plans coordinated at the level of the river basin district or unit of management. The plans must contain the following information (European Union 2007):

- Delineation of the areas exposed to significant flood risk.

- Flood hazard maps and flood risk maps.

- Definition and description of appropriate flood risk management objectives focusing on (1) reduction of potential adverse consequences for protected assets (human health, the environment, cultural heritage, and economic activity); (2) nonstructural flood prevention measures; and (3) reduction of the likelihood of flooding.

- Measures for achieving the objectives.

- Taking into account costs and benefits, flood conveyance and retention areas, natural floodplains, the environmental objectives of the WFD, soil and water management, spatial planning, land use, nature conservation, navigation, and port infrastructure.

- Taking into account all aspects of flood risk management that focus on (1) prevention, protection, 
preparedness; (2) flood forecasts; and (3) early warning systems.

- Where appropriate, the characteristics of the particular river basin or subbasin.

- Where appropriate, promotion of sustainable land use practices.

- Where appropriate, improvement of water retention.

- Observation of the upstream/downstream principle.

For the periodical reviews of the flood risk management plans every six years, the following information shall be added:

- Any changes or updates since the publication of the previous version of the flood risk management plan.

- Summary of the reviews carried out in compliance with Article 14 of the Flood Risk Management Directive.

- Assessment of the progress made towards the achievement of the objectives.

- Description and explanation of any measures foreseen in the earlier version of the flood risk management plan that were planned to be undertaken and have not been carried out.

- Description of any additional measures since the publication of the previous version of the flood risk management plan.

The required periodical reviews, reassessments, and updates under the Flood Risk Management Directive lead to continued examination of flood risk management practices and may thus contribute to maintenance of adequate flood risk awareness (Müller 2010a).

\section{Initial Structural Situation}

The Flood Risk Management Directive is to be understood as complementary to the Water Framework Directive (Müller 2011). That is why it makes sense to include the river basin districts in the comparison between the water management structures. In accordance with Article 3 of the Flood Risk Management Directive, many EU member states use the Water Framework Directive watercourse system also for the considerations under the Flood Risk Management Directive. Many river basins of Europe are transnational and thus require agreement and coordination between countries.

The following comparison between Austria, the Czech Republic, Germany, and the Netherlands shows that the legislation and the relevant authority structures are very different in each country and that this situation makes the agreement and coordination process more demanding.

In most cases the legislations related to water and construction and spatial planning are of a centralized nature and so there are uniform specifications for the implementation process in countries like the Czech Republic and the Netherlands. In federal countries such as Austria and Germany, however, more legislative authority is conferred on the states.
Although water law is regulated by the central government in Austria, the construction and spatial planning laws are under the authority of the individual federal states. In Germany, the central government sets out the legal framework for all these issues, but the detailed statutory provisions are under the authority of the federal states. Most of the regional planning authority lies with the regions. The development of strategies and methods for the implementation of the Flood Risk Management Directive is centralized in some countries (the Czech Republic) and decentralized in others (Germany). For the sake of coordinated implementation despite decentralized structures, countries like Germany have set up joint working groups between the central government and the federal states to coordinate recommendations for the implementation of the directive (LAWA (2010a, 2010b)). For technical coordination issues within the river basin districts, there are river basin communities within Germany and international river commissions (for example, the International Commission for the Protection of the Rhine-ICPR, and the International Commission for the Protection of the Elbe River-ICPER) on the transnational level. These communities or commissions work together on specific coordination issues related to the given river basin district. The approach can vary between different international river district commissions. Some commissions, such as the ICPER in the Elbe River basin, intend to establish an internationally coordinated flood risk management plan whereas other commissions envisage developing mutually coordinated national flood risk management plans for the river basin (for instance, the International Commission for the Protection of the Danube River-ICPDR).

The structures of the authorities responsible for implementation also are very different. In the Czech Republic, river basin management is performed by five river basin administrations (Povodi), which do not coincide with the political administrative borders. In Germany, river basin management is the responsibility of the German states, except for federal waterways. Each German state has its own water management structure. Saxony, for instance, has set up a public enterprise that is responsible for state-owned watercourses and dams. Other waters are the responsibility of the municipalities.

The varying legislative authorities and water management responsibilities make the Flood Risk Management Directive implementation process a big challenge for stakeholders at all levels.

\section{Technical Implementation of the European Flood Risk Management Directive}

The implementation of the Flood Risk Management Directive is also a challenge on the technical level. The different initial situations on the technical level in each of the EU member states must be adjusted during the next few years and eventually harmonized in compatible flood risk management 
plans. The following is a comparison between the technical approaches of different EU member states. The comparison is based on the implementation steps laid down in the Flood Risk Management Directive. To cover the differences within countries with a decentralized structure, the comparison includes a selection of independently acting authorities on a subnational level.

\subsection{Preliminary Flood Risk Assessment}

The first step of implementation is the preliminary assessment of the flood risk. For this purpose, the EU member states must make a decision on the drainage system to be considered and on the information and criteria required for significance determination. Due to their topographic situation, the Netherlands have decided to identify the whole country as potentially affected. By summer 2010, some of the EU member states had not made up their minds how the preliminary assessment would be made. Other EU member states, for example the Czech Republic, follow a centrally specified methodology.

Within the scope of the preliminary flood risk assessment, it is important to know exactly what drainage system is to be considered. Most states use the same watercourse system they use for reporting under the Water Framework Directive. There are differences in terms of river basins, some of the states refer to the entire Water Framework Directive basin, whereas other states consider river basins with a surface area of more than $10 \mathrm{~km}^{2}$ only. In many states, the assessment includes additional watercourses exposed to flood risks known from the past or from flood protection concepts.

The next preliminary assessment phase is to identify the exposure and vulnerability and finally to define the areas showing a significant risk. These areas need to be delineated in an appropriate way and undergo all further observations required under the Flood Risk Management Directive. Table 2 lists the major significance criteria of selected countries or federal states. The states use very different data bases

Table 2. Significance criteria for preliminary flood risk assessment

\begin{tabular}{|c|c|c|}
\hline $\begin{array}{l}\text { EU Member State } \\
\text { (Federal State) }\end{array}$ & $\begin{array}{l}\text { Identification of Affected Watercourses or River Basins } \\
\text { under Article } 4 \text { of the FRMD }\end{array}$ & $\begin{array}{l}\text { Identification of Affected Water Subsystems under } \\
\text { Article } 5 \text { of the FRMD }\end{array}$ \\
\hline $\begin{array}{l}\text { Germany } \\
\text { (Saxony) }\end{array}$ & $\begin{array}{l}\text { Watercourses with flood protection concepts or declared } \\
\text { floodplains; other identified waters }\end{array}$ & $\begin{array}{l}\text { Basic data from flood protection concepts, expert } \\
\text { knowledge, damage potential, affected population, IPPC } \\
\text { facilities, cultural heritage }\end{array}$ \\
\hline $\begin{array}{l}\text { Germany } \\
\text { (Saxony-Anhalt) }\end{array}$ & $\begin{array}{l}\text { Entire watercourse system according to WFD, other } \\
\text { identified waters }\end{array}$ & 5 of 11 LAWA criteria (LAWA 2009) have to be fulfilled \\
\hline $\begin{array}{l}\text { Germany } \\
\text { (Thuringia) }\end{array}$ & $\begin{array}{l}147 \text { water bodies with floodplains to be defined according } \\
\text { to Government of Germany (2009) }\end{array}$ & $\begin{array}{l}\text { Damage potential, affected population, IPPC facilities, } \\
\text { cultural heritage, protected areas }\end{array}$ \\
\hline $\begin{array}{l}\text { Germany } \\
\text { (Brandenburg) }\end{array}$ & $\begin{array}{l}\text { Flood-prone water bodies according to Government of } \\
\text { Germany (2009), other identified water bodies }\end{array}$ & $\begin{array}{l}\text { Expert knowledge, affected population, IPPC facilities, } \\
\text { pedological information }\end{array}$ \\
\hline $\begin{array}{l}\text { Germany } \\
\text { (North Rhine-Westphalia) }\end{array}$ & Watercourses with flood action plans and hazard maps & $\begin{array}{l}\text { Damage potential }>€ 500,000 \text { per settlement area, IPPC } \\
\text { facilities, cultural heritage }\end{array}$ \\
\hline Austria & $\begin{array}{l}\text { Entire drainage system according to WFD, other identified } \\
\text { watercourses }\end{array}$ & $\begin{array}{l}\mathrm{HQ}_{200} \text { Austrian flood risk zoning, affected population, } \\
\text { affected infrastructure, pollutant sources, protected areas }\end{array}$ \\
\hline Czech Republic & Entire watercourse system according to WFD & $\begin{array}{l}\mathrm{HQ}_{100} \text { for settlement areas, } \geq 25 \text { inhabitants affected per } \\
\text { settlement area, damage potential } \geq \text { CZK } 70 \text { million/year, } \\
\text { IPPC facilities, cultural heritage, expert knowledge, } \\
\text { protected areas }\end{array}$ \\
\hline $\begin{array}{l}\text { Belgium } \\
\text { (Wallonia) }\end{array}$ & Entire watercourse system & $\begin{array}{l}\text { Basic data from flood control plan (PLUIES), damage } \\
\text { potentials, affected population, expert knowledge }\end{array}$ \\
\hline Italy & First and second-order watercourses & $\begin{array}{l}\text { Basic data from flood control plans (PAI), damage } \\
\text { potentials, affected population, affected infrastructure, } \\
\text { expert knowledge }\end{array}$ \\
\hline Hungary & $\begin{array}{l}\text { Watercourses according to state regulation, waters with } \\
\text { state-owned flood control systems, waters with basins } \\
>100 \mathrm{~km}^{2} \text {, other identified waters }\end{array}$ & $\begin{array}{l}\mathrm{HQ}_{100} \text { for settlement areas, damage potentials, affected } \\
\text { population, expert knowledge }\end{array}$ \\
\hline Cyprus & Watercourses identified by historical flood analyses & $\begin{array}{l}\text { Damage potentials, affected population, expert knowledge, } \\
\text { land use }\end{array}$ \\
\hline Latvia & Main rivers and tributaries, polders & Damage potentials, affected population, expert knowledge \\
\hline
\end{tabular}

Note: FRMD-Flood Risk Management Directive; $\mathrm{HQ}_{T}-$ Flood flow at a recurrence interval of T years; IPPC-integrated pollution and prevention control; LAWA-German Working Group on Water Issues of the Federal States and the Federal Government; PAI-Po Basin District Authority; PLUIES-Flood Prevention Scheme on River Sinistrés in Wallonia; WFD-Water Framework Directive. 
and thus have to apply different significance criteria. Once the first cycle of implementation of the Flood Risk Management Directive with the first flood risk management plans is complete, the available data basis will be much better. Therefore, it can be assumed that after the second assessment cycle in 2018 and in all subsequent reviews every six years, the preliminary flood risk assessments will be much better harmonized and comparable.

Significantly affected watercourses are normally delineated in maps. Many states use a scale of 1:100,000 for the mapping of significant areas for the Water Framework Directive river basins or subbasins. In addition to the topography, most of those maps show the watercourse system, administrative borders, settlement areas and some land uses. Figure 1 is one example for the preliminary flood risk assessment map of a part of the Czech Republic. The map shows that preliminary risk areas (red-colored rivers) are located mainly in the north (lower part) of the catchment area.

\subsection{Flood Hazard and Flood Risk Maps}

The second implementation step is to establish the flood hazard maps and flood risk maps for the areas identified with a significant flood risk. Many member states were still working on the mapping methodology when the investigation was carried out in 2011, so the present document is only a first brief outline. Several EU projects, for example, the LABEELBE Adaptation to Flood Risk project for transnational cooperation on the provision for risks in the Elbe River basin, known as the LABEL project (LABEL Website 2011) and the FloodWise project for improving cross-border flood risk management in European river basins that cross national borders (FloodWise Website 2011) have tested first developed mapping methods in pilot areas. They have been evaluated by the EU as well and are very representative for flood risk management aspects.

The flood probabilities and map scales used in each of the states may vary according to local conditions or circumstances. Some of the countries include additional data in the maps such as river bed loads or drifting ice. Table 3 gives a summary of flood hazard mapping in selected member states. The Events $\left(\mathrm{HQ}_{T}\right)$ column shows the recurrence intervals for the events and the next column the occurrence of flooded areas and water depths for $\mathrm{HQ}_{T}$ in the maps. The contents displayed in the hazard maps are quite similar in each of the member states. The major differences concern the

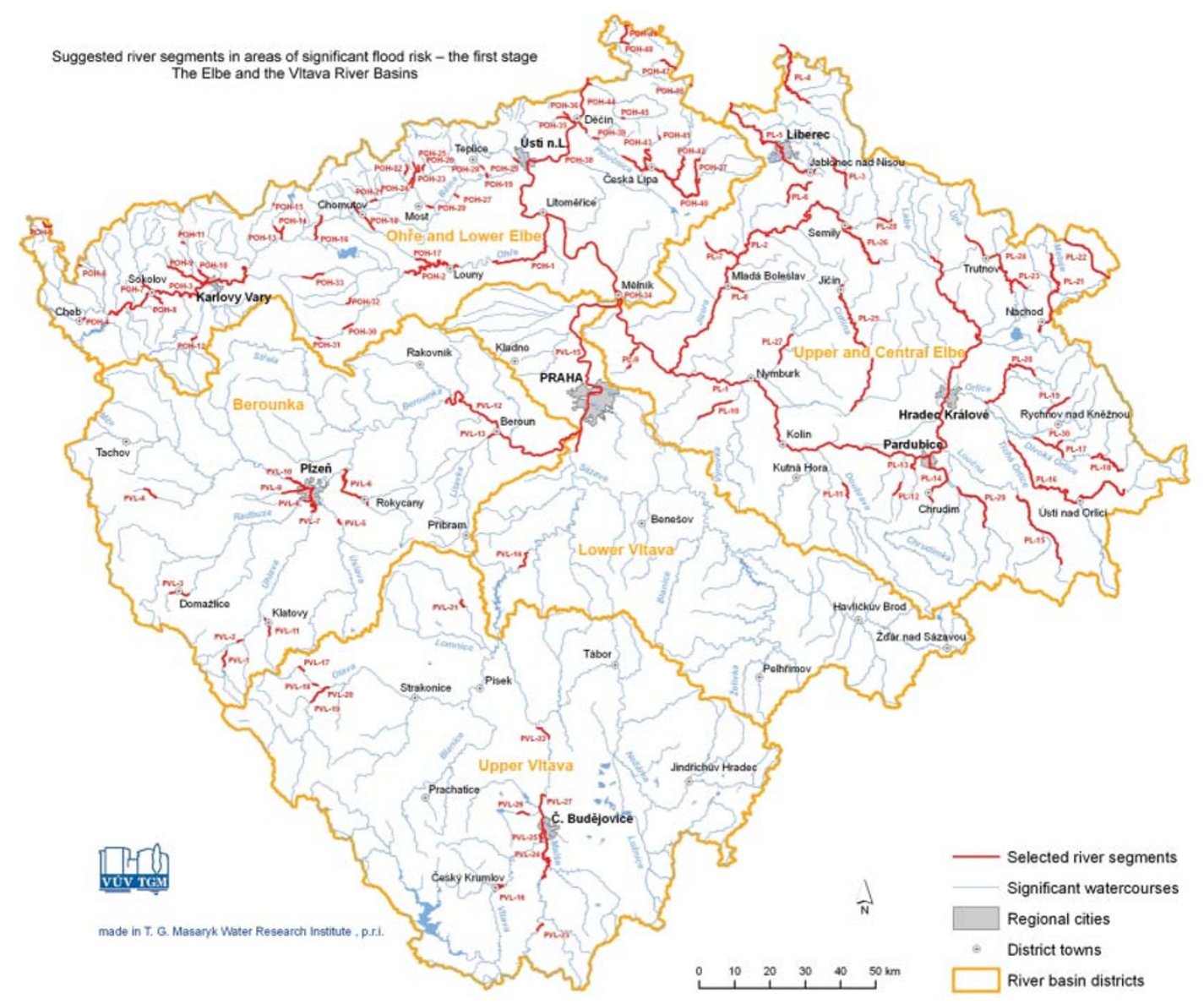

Figure 1. Preliminary flood risk assessment in a part of the Czech Republic Source: T. G. Masaryk Water Research Institute (2011). 
Table 3. Data shown in flood hazard maps

\begin{tabular}{|c|c|c|c|c|c|c|c|c|}
\hline \multirow[t]{2}{*}{ EU Member State (Federal State) } & \multicolumn{2}{|c|}{ Scale } & \multicolumn{3}{|c|}{ Events $\left(H_{T}\right)$} & \multicolumn{3}{|c|}{ Flooded Areas + Water Depths for $\mathbf{H Q}_{T}$} \\
\hline & Generation & Representation & $T_{\text {low }}$ & $T_{\text {medium }}$ & $T_{\text {high }}$ & $T_{\text {low }}$ & $T_{\text {medium }}$ & $T_{\text {high }}$ \\
\hline Germany (Saxony) & $1: 10,000$ & $1: 10,000$ & $200-300$ & 100 & $20 ; 25$ & Yes & Yes & Yes + Q \\
\hline Germany (Saxony-Anhalt) & $1: 10,000$ & $\begin{array}{l}1: 5,000 \\
1: 10,000\end{array}$ & 200 & 100 & $10 ; 20$ & Yes & Yes & Yes \\
\hline Germany (Thuringia) & $1: 10,000$ & $1: 10,000$ & 200 & 100 & 20 & Yes & Yes & Yes $+v$ \\
\hline Germany (Brandenburg) & $1: 10,000$ & $\begin{array}{l}1: 2,500 \\
1: 10,000\end{array}$ & 200 & 100 & 10 & Yes & Yes & Yes \\
\hline Germany (North Rhine-Westphalia) & $1: 5,000$ & $\begin{array}{l}1: 50,000 \\
1: 25,000\end{array}$ & Extreme & 100 & $10 ; 20$ & Yes & Yes & Yes $+v$ \\
\hline Austria & $1: 25,000$ & $1: 25,000$ & 300 & 100 & 30 & Yes & Yes & Yes + Q \\
\hline Netherlands & $1: 50,000$ & $1: 50,000$ & $1,0001,250$ & 100 & 10 & Yes & Yes & Yes \\
\hline Czech Republic & $1: 10,000$ & $1: 10,000$ & 500 & 100 & 20 & Yes & Yes & Yes $+v$ \\
\hline Belgium (Wallonia) & $1: 10,000$ & $1: 10,000$ & 5001,000 & 100 & $25 ; 50$ & Yes & Yes & No \\
\hline Italy & $1: 10,000$ & $\begin{array}{l}1: 10,000 \\
1: 25,000\end{array}$ & 500 & $100-200$ & $20-50$ & Yes & Yes & Yes $+\mathrm{v}$ or $+\mathrm{Q}$ \\
\hline Hungary & $1: 5,000 ; 1: 10,000$ & $\begin{array}{l}1: 5,000 \\
1: 10,000\end{array}$ & 100 & 20 & 5 & Yes & Yes & Yes $+v$ \\
\hline Cyprus & $1: 10,000$ & $1: 10,000$ & $200-300$ & 100 & $10 ; 20$ & Yes & Yes & No \\
\hline
\end{tabular}

Note: $\mathrm{HQ}_{T}-$ Flood flow at a recurrence interval of $T$ years; $\mathrm{Q}-$ Runoff; $\mathrm{v}-$ flow velocity.

probabilities (recurrence intervals) assumed for the events shown in the maps, which is due to different local conditions or safety philosophies.
Figures 2 and 3 show the flood hazard maps of Thuringia (Germany) and the Netherlands as an example of the map details shown in Table 3. The layout of the hazard maps is

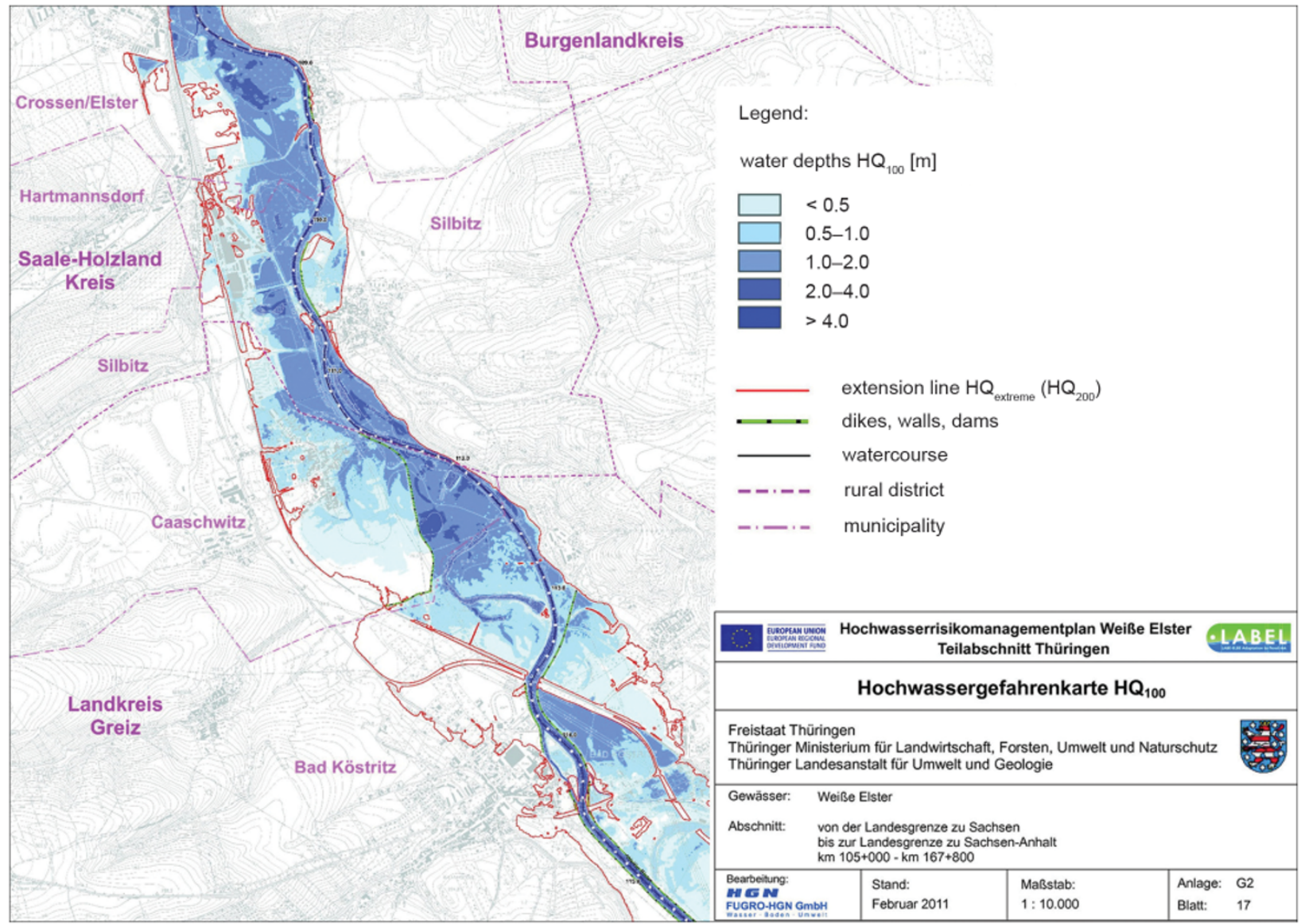

Figure 2. Extract from the flood hazard maps of Thuringia (Germany)

Source: TLUG (2011). 


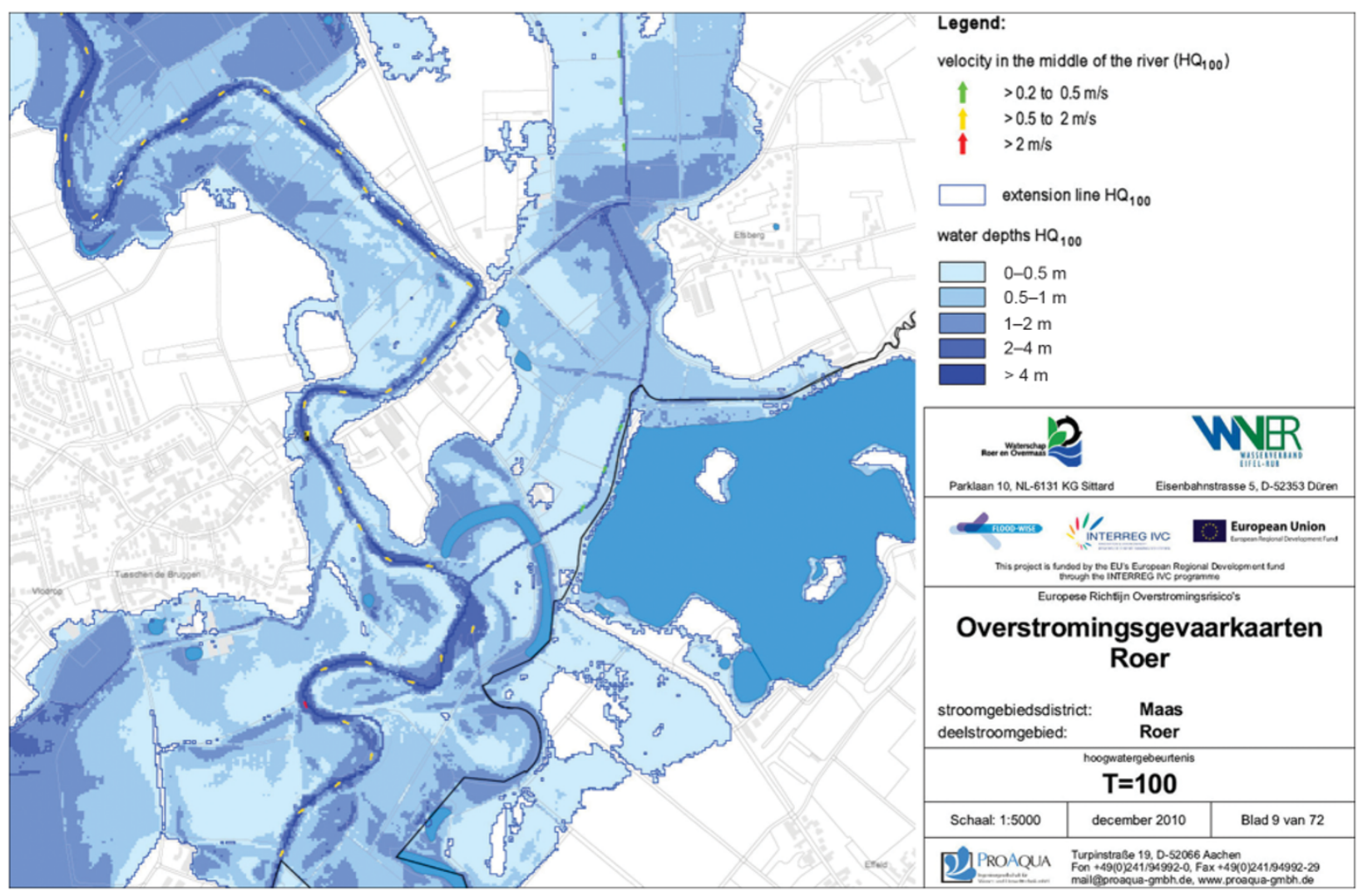

Figure 3. Extract from the flood hazard maps of the Netherlands

Source: RORWA (2011).

very similar in spite of different scales. The gradation of water depth classes displayed is the same. The map of Thuringia also indicates the extent of the extreme event as a red line. These maps are very comparable.

The differences between states in flood risk mapping are greater than in hazard mapping because of greater differences in vulnerability considerations. Figure 4 and 5 show the differences in the flood risk maps of Saxony (D) and the Czech Republic. Table 4 gives a summary for selected states. Layout and content of the shown risk maps are different. The map of Saxony shows in addition to land use types more other information such as inhabitants per municipality and other objects. The comparison of the risk maps is much more difficult.

\subsection{Flood Risk Management Plans}

The third implementation step is to set up flood risk management plans. In 2011, the basic ideas and preparatory work of each of the member states showed great differences. Generally, the states were still working on the preliminary flood risk assessment as well as on the hazard and risk mapping methods. So in most cases there were no exact outlines for how to structure and establish flood risk management plans. However, the flood risk management plans of most of the surveyed member states will cover the following aspects:
- Introduction (general description of flood risk management; general description of the spatial extent; list of responsible authorities).

- Preliminary flood risk assessment (brief description of the preliminary flood risk assessment procedure and results; map showing the water routes exposed to potentially significant flood risk).

- Description of the flood hazard and flood risk (brief description of the contents of the flood hazard maps and flood risk maps; flood hazard maps; flood risk maps; conclusions from the maps).

- Description of the defined objectives (preventive land use; natural water retention; technical flood protection; precautionary building; preventive action against risks; precautionary information; precautionary behavior; emergency preparedness for defence and civil protection).

- Actual/target analysis (evaluation of the current situation with regard to the objective to be achieved).

- Identification of potential measures (identification of measures to be taken and comparative assessment of alternative actions).

- Summary list of measures by priority (envisaged implementation actions; methodology for supervising their implementation). 


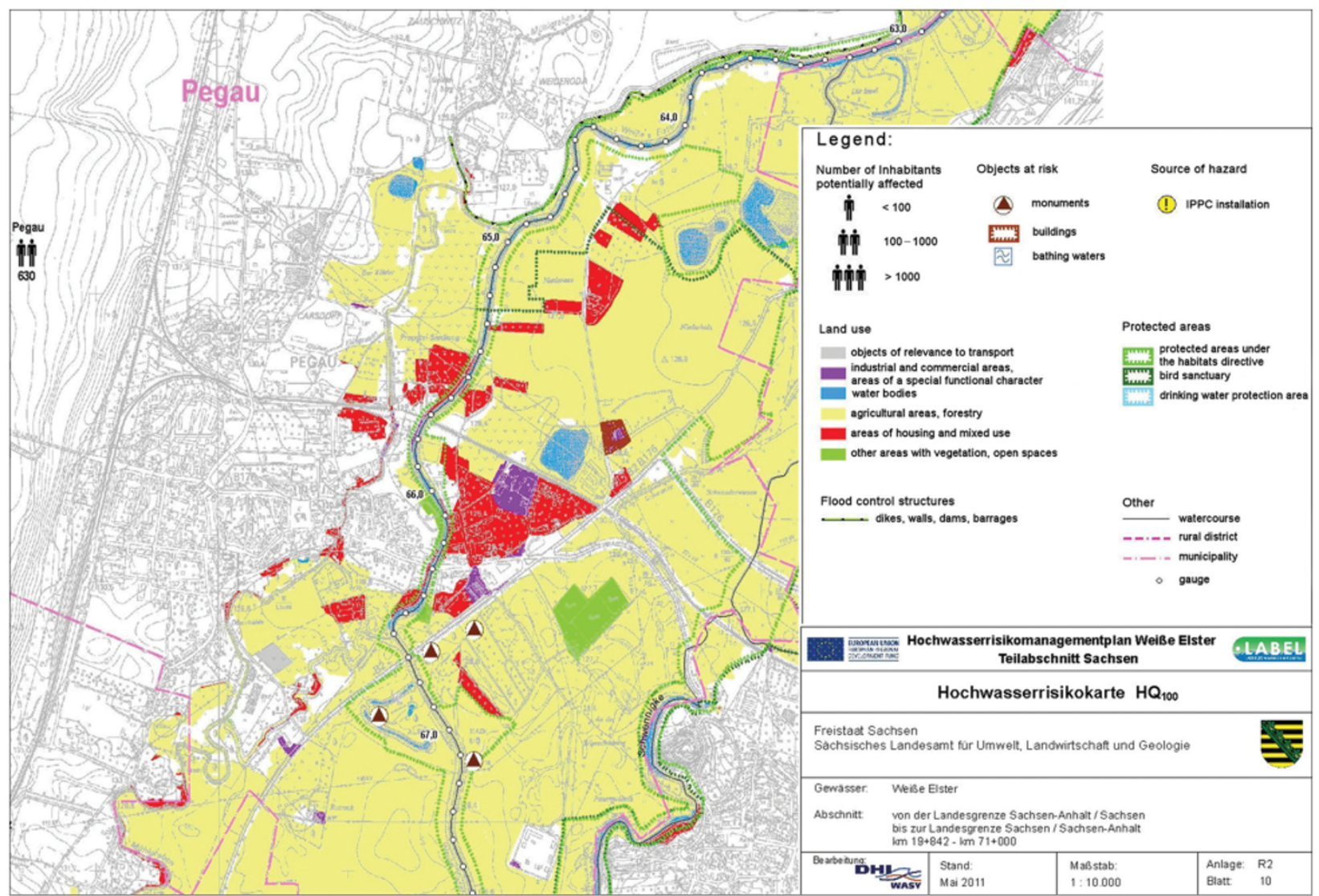

Figure 4. Extract from the flood risk maps of Saxony

Source: LfULG (2011).

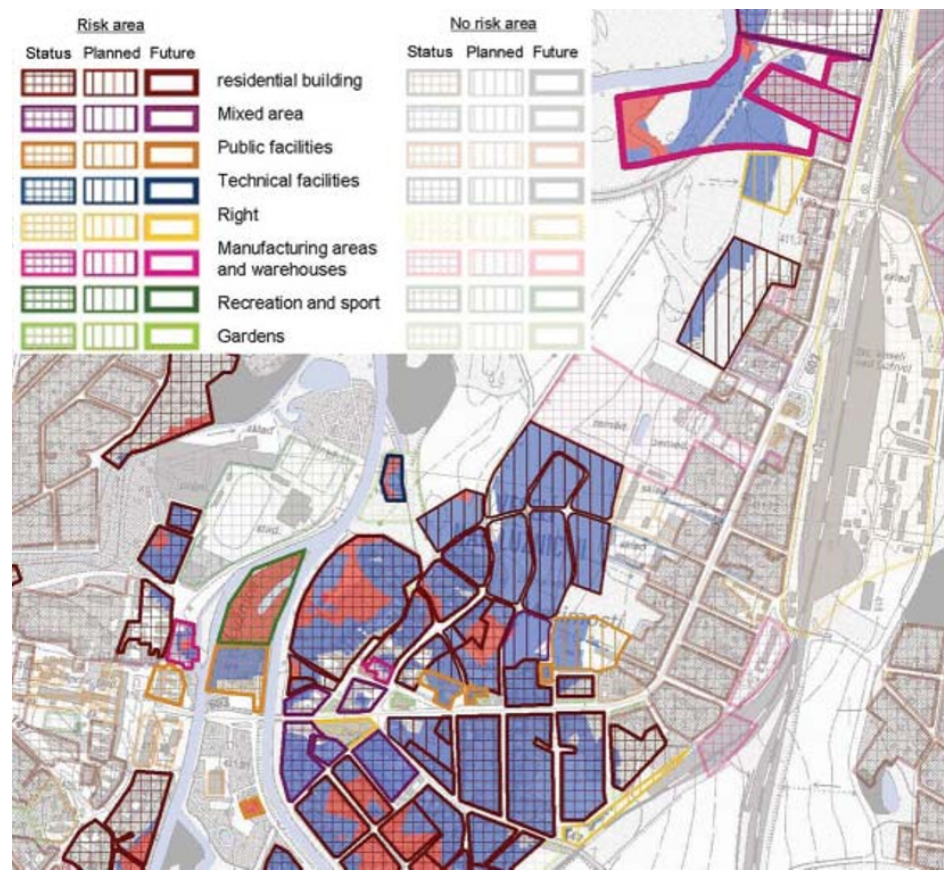

Figure 5. Extract from the flood risk maps of the Czech Republic Source: MECR (2011). 
Table 4. Data shown in flood risk maps

\begin{tabular}{|c|c|c|c|c|c|}
\hline $\begin{array}{l}\text { EU Member State } \\
\text { (Federal State) }\end{array}$ & Scale & $\begin{array}{l}\text { (A) Inhabitants per } \\
\text { municipality } \\
\text { (B) Number } \\
\text { of inhabitants }\end{array}$ & $\begin{array}{l}\text { According to (A) } 6 \text { land } \\
\text { use types } \\
\text { (B) } 9 \text { land use types } \\
\text { (C) } 25 \text { land use types }\end{array}$ & $\begin{array}{l}\text { Information to Potential } \\
\text { Environmental Pollution } \\
\text { (A) IPPC facilities } \\
\text { (B) Drinking water } \\
\text { protection areas } \\
\text { (C) Healing springs } \\
\text { (D) Bathing waters } \\
\text { (E) Nature } \\
\text { conservation areas }\end{array}$ & $\begin{array}{l}\text { Other Aspects } \\
\text { (A) Monuments } \\
\text { (B) Sewage plants } \\
\text { (C) Sediment \& river } \\
\text { bed load transport } \\
\text { (D) Sensitive } \\
\text { buildings (hospital...) }\end{array}$ \\
\hline Germany (Saxony) & $1: 10,000$ & A & $\mathrm{B}$ & $\mathrm{A}, \mathrm{B}, \mathrm{C}, \mathrm{D}$ & A \\
\hline Germany (Saxony-Anhalt) & $1: 10,000$ & A & $\mathrm{B}$ & $\mathrm{A}, \mathrm{B}, \mathrm{C}, \mathrm{D}$ & A \\
\hline Germany (Thuringia) & $1: 10,000$ & A & $\mathrm{B}$ & $\mathrm{A}, \mathrm{B}, \mathrm{C}, \mathrm{D}$ & A \\
\hline Germany (Brandenburg) & $1: 10,000$ & A & $\mathrm{C}$ & $\mathrm{A}, \mathrm{B}, \mathrm{C}, \mathrm{D}$ & A, B \\
\hline $\begin{array}{l}\text { Germany (North } \\
\text { Rhine-Westphalia) }\end{array}$ & $\begin{array}{l}1: 50,000 \\
1: 25,000\end{array}$ & $\mathrm{~A}$ & A & $\begin{array}{l}\text { A, B, C, D } \\
+ \text { FFH + SPA }\end{array}$ & A \\
\hline Austria & $1: 25,000$ & $\begin{array}{l}\text { Inhabitants per } \\
\text { population grid }\end{array}$ & $\begin{array}{l}\text { A }+ \text { no. of employed } \\
\text { persons }\end{array}$ & $\mathrm{A}, \mathrm{B}, \mathrm{D}, \mathrm{E}$ & $\mathrm{B}, \mathrm{C}$ \\
\hline Netherlands & $1: 50,000$ & $\mathrm{~B}$ & $\begin{array}{l}\text { Economic activity in the } \\
\text { area }\end{array}$ & $\mathrm{A}, \mathrm{B}, \mathrm{D}, \mathrm{E}$ & None \\
\hline Czech Republic & $1: 10,000$ & B & $\mathrm{B}$ & $\mathrm{A}, \mathrm{B}, \mathrm{D}, \mathrm{E}$ & $\mathrm{D}$ \\
\hline Belgium (Wallonia) & $1: 10,000$ & Number per building & NACE code & $\mathrm{A}, \mathrm{B}, \mathrm{D}, \mathrm{E}$ & None \\
\hline Italy & $\begin{array}{l}1: 10,000 \\
1: 25,000\end{array}$ & A & CORINE land use types & $\mathrm{A}, \mathrm{B}, \mathrm{D}, \mathrm{E}$ & $\mathrm{C}$ \\
\hline Hungary & $\begin{array}{l}1: 5,000 \\
1: 10,000\end{array}$ & $\mathrm{~B}$ & 6 CORINE land use types & $\mathrm{A}, \mathrm{B}, \mathrm{D}, \mathrm{E}$ & None \\
\hline Cyprus & $1: 10,000$ & B & B (probably) & $\mathrm{A}, \mathrm{B}, \mathrm{D}, \mathrm{E}$ & None \\
\hline
\end{tabular}

Note: CORINE-EU Coordination of Information on the Environment; FFH-Habitats Directive areas; IPPC-integrated pollution and prevention control; NACE-Statistical Classification of Economic Activities in the European Community; SPA-Birds Directive areas.

- Strategic Environmental Assessment (SEA) and public information (description of the procedure to be used when carrying out a SEA; actions for information, public inquiry and consultations; description of coordination with the Water Framework Directive).

In Germany, the LAWA working group came up with a methodology and structuring proposal for the development of the flood risk management plans (LAWA 2010b) in 2010. This proposal has been elaborated in more detail within the scope of the EU projects LABEL and FloodWise and was tested in the pilot areas of the Weisse Elster River (Thuringia, Saxony, and Saxony-Anhalt) and Elbe River (border Brandenburg and Saxony near the small city Mühlberg). The complete structure for the flood risk management plans is published in Walther (2011). During practical implementation in the mentioned pilot areas, it became quickly obvious that the available data basis is crucial to the quality of flood risk management plans.

\section{Evaluation}

The process of implementing the Flood Risk Management Directive started out successfully in the EU member states.
The structural, technical, and data requirements are different in each of the EU member states that to achieve the objectives laid down in the Flood Risk Management Directive it is necessary to work together on an international basis in each of the cross-border river basin districts. The international river basin commissions, such as ICPR (Rhine) or ICPER (Elbe), play an important part in this cooperation. Regardless of whether the commissions agreed on a joint flood risk management plan or on mutually coordinated national parts of a flood risk management plan, cooperation within river basins helps to increase mutual confidence and improve the exchange of data. This leads to better coordination within the river basins and will cause an alignment of technical procedures in the medium run.

Interviews with the FloodWise project (FloodWise Website 2011) have shown that transnational cooperation on the working level is considered to be very important, because there are many operative aspects of flood risk management with increasing importance in individual situations. Cooperation in terms of flood forecasting and information is an example. The observation of the upstream-downstream principle is especially important.

The implementation of the Flood Risk Management Directive with its components of preliminary flood risk 
assessment, creation of flood hazard and risk maps, and development of flood risk management plans will imply many detailed issues of a legal, scientific, and social nature yet to be solved. The current state of knowledge and so far unsolved technical issues for the implementation of the EU Flood Risk Management Directive are described in Müller (2010b). There has been no final outcome, for instance, as to what impact the climate changes will have on flood risk management. Although there are already good descriptions of flood-related hazards or exposures on a broad basis of water management information, there still is uncertainty or lack of clarity about what vulnerability information is required for a comprehensive risk assessment. That is why quite a number of member states (including Germany via RIMAX-Risk Management of Extreme Flood Events) or current EU projects communicate new results and latest findings, which need to be checked and verified for their practical applicability and reliability. Science plays a decisive part in the harmonization of the implementation of the Flood Risk Management Directive on the technical level, because well-coordinated technical fundamentals and methods are the only way to help to have a better understanding of flood events and take better action especially in the case of transnational imminent situations. For instance, if the flood risk maps are drawn up according to the same methodology and with the same contents, and if the contents of the legends are identical, it will be possible to understand the information shown in the maps and respond by appropriate action much quicker.

The international projects have also shown the water managements to be currently the decisive actors in the implementation of the Flood Risk Management Directive. The EU member states must increase their efforts to build flood awareness on all social levels and in all areas of the society. An integrated (interdepartmental) flood risk management approach requires flood issues to be considered by many other technical and structural departments and to be included in the implementation of their measures and actions. Town and country planners or bridge constructors, for instance, could contribute to the reduction of flood risks by floodadapted designs. Last but not least, the individual responsibility and preparedness of the people living and working in flood risk zones should not be left unmentioned. The only way to bring down the risk is to build a keen flood risk awareness associated with individual precautions based on the data and information provided by water administrations or other structural bodies.

\section{Conclusion}

The EU member states are working intensively on the implementation of the Flood Risk Management Directive (European Union 2007). This study, carried out in 2010 within the scope of the LABEL and FloodWise projects, shows the basic structural and data conditions to be very different across member states. International cooperation in flood risk management is very important to properly reduce flood risk for human, economic, and natural assets in most cross-border river basins. The international river basin commissions are of decisive importance in this respect.

On the way towards the successful implementation of the Flood Risk Management Directive with its components of preliminary flood risk assessment, creation of flood hazard and risk maps, and development of flood risk management plans, it is necessary to find scientific solutions to many detailed issues of a legal, scientific, and social nature.

Data availability is a key item for successful implementation of the flood risk management plans. Once the first cycle of implementation of the Flood Risk Management Directive with the first flood risk management plans is complete, the available data bases in the EU member states will be much better. It can be assumed that after the second assessment cycle (in 2018) and all subsequent reviews every six years there will be much better comparability and harmonization of flood risk management across the EU.

The Flood Risk Management Directive will lead to higher flood risk awareness in Europe with a gradual change from a safety culture to a risk culture. Modern risk culture means not only preventive actions at reasonable expense, but includes the willingness to accept damage in case of extreme events and the willingness to ensure open communication of risks. The EU flood risk management plans are excellent tools for this purpose.

\section{References}

European Union. 1996. Directive 96/61/EC of the European Parliament and of the Council of 24 September 1996 Concerning Integrated Pollution Prevention and Control (OJ L 257, 10.10.1996), as Last Amended by Regulation (EC) No 166/2006 of the European Parliament and of the Council (OJ L 33, 04.02.2006).

European Union. 2000. Directive 2000/60/EC of the European Parliament and of the Council of 23.10.00 Establishing a Framework for Community Action in the Field of Water Policy-EU Water Framework Directive (OJ L 327, 22.12.2000).

European Union. 2007. Directive 2007/60/EC of the European Parliament and of the Council of 23 October 2007 on the Assessment and the Management of Flood Risks (OJ L 288, 6.11.2007). http://eur-lex. europa.eu/LexUriServ/LexUriServ.do?uri=OJ:L:2007:288:0027: 0034:EN:PDF

FloodWise Website. 2011. http://flood-wise.eu.

Government of Germany. 2009. German Act on the Regulation of Water Balance (Wasserhaushaltsgesetz vom 31. Juli 2009 (BGBl. I S. 2585), das durch Artikel 4 Absatz 76 des Gesetzes vom 7. August 2013 (BGBl. I S. 3154) geändert worden ist)). http://www.gesetze-iminternet.de/bundesrecht/whg_2009/gesamt.pdf (in German).

Grünewald, U. 2003. Flood Prevention in Germany-Learning from Disaster 2002 in the Elbe Basin (Hochwasservorsorge in Deutschland-Lernen aus der Katastrophe 2002 im Elbegebiet). Deutsches Komitee für Katastrophenvorsorge e.V.; Schriftenreihe des DKKV 29, Bonn 2003 (in German).

LABEL (EU Project on river Labe-Elbe) Website. 2011. http://www. label-eu.eu. 
LAWA (Bund/Länder-Arbeitsgemeinschaft Wasser [German Working Group on Water Issues of the Federal States and the Federal Government]). 2009. Procedure for the Preliminary Assessment of Flood Risk by EU Flood Risk Management Directive (Vorgehen bei der vorläufigen Bewertung des Hochwasserrisikos nach EU-HWRM$R L)$. Saarbrücken: LAWA (in German).

LAWA (Bund/Länder-Arbeitsgemeinschaft Wasser [German Working Group on Water Issues of the Federal States and the Federal Government]). 2010a. Recommendations for the Establishment of Flood Hazard Maps and Flood Risk Maps (Empfehlung zur Aufstellung von Hochwassergefahrenkarten und Hochwasserrisikokarten). Dresden: LAWA.

LAWA (Bund/Länder-Arbeitsgemeinschaft Wasser [German Working Group on Water Issues of the Federal States and the Federal Government]). 2010b. Recommendations for the Establishment of Flood Risk Management Plans (Empfehlung zur Aufstellung von Hochwasserrisikomanagementplänen). Dresden: LAWA.

LfULG (Landesamt für Umwelt, Landwirtschaft und Geologie [Saxon State Agency for Environment, Agriculture, and Geology]). 2011. Frame EU Project LABEL, Working Group RISK. Dresden: LfULG.

T. G. Masaryk Water Research Institute. 2011. Frame EU Project LABEL, Working Group RISK. Prague: T. G. Masaryk Water Research Institute.

MECR (Ministerstvo životního prostředí [Ministry of the Environment of the Czech Republic]). 2011. Frame EU Project LABEL, Working Group RISK. Prague: MECR.
Müller, U. 2010a. Flood Risk Management-Theory and Practice (Hochwasserrisikomanagement-Theorie und Praxis). Wiesbaden: Springer-Vieweg Verlag (in German).

Müller, U. 2010b. Knowledge and Open Questions Concerning the Implementation of the EU Flood Risk Management Directive (Wissensstand und offene Fragen zur Umsetzung der EG-Hochwasserrisikomanagementrichtlinie). Hydrologie und Wasserbewirtschaftung 54 (3): 179-191 (in German).

Müller, U. 2011. Implementation of the European Water Framework Directive and the European Flood Risk Management DirectiveOpposition or Opportunity in River Basin Management? (Umsetzung der Europäischen Wasserrahmen- und der Europäischen Hochwasserrisikomanagementrichtlinie-Widerspruch oder Chance in der Flussgebietsbewirtschaftung?). Korrespondenz Wasserwirtschaft 4 (3): 141-147 (in German).

RORWA (Roer and Overmaas Regional Water Authority). 2011. Frame EU Project Flood-Wise. Sittard: RORWA.

TLUG (Thüringer Landesanstalt für Umwelt und Geologie [Thuringian State Institute for Environment and Geology]). 2011. Frame EU Project LABEL, Working Group RISK. Jena: TLUG.

Walther, J. 2011. Flood Risk Management Plan Weisse Elster (Hochwasserrisikomanagementplan Weiße Elster); In: Report Series of the Forum for European Flood Risk Management Policy (Berichtsreihe des Forums zur Europäischen Hochwasserrisikomanagementrichtlinie, No. 3 (2011), edited by R. Jüpner and U. Müller, 61-73. Aachen: Shaker Verlag (in German).

Open Access This article is distributed under the terms of the Creative Commons Attribution License which permits any use, distribution, and reproduction in any medium, provided the original author(s) and source are credited. 